\title{
Kekaburan Norma dalam Pasal 55 Undang-Undang Nomor 24 Tahun 2011 Tentang Badan Penyelenggaraan Jaminan Sosial
}

\author{
Andrias Winarno, Bambang Sugiri dan Yuliati Cholil \\ winarnoandrias7@gmail.com \\ Universitas Brawijaya, Malang
}

\begin{abstract}
Keywords: $\quad$ Abstract
Obscurity Norm; The issues that will be examined in this article relate to the vagueness of norms in Article BPJS Law; 19 paragraph (1) and paragraph (2) in conjunction with Article 55 of the BPJS Law. The Classification of confusion of norms occurs because there are no clear boundaries regarding the elements Crime. in the article so that in practice there is some information that can be provided in BPJS contributions. This paper will examine what actually urges criminal acts in the BPJS Law and what the concept of classification should be. This article uses a normative legal research method with a statute approach and a conceptual approach. The results show that the urgency of regulating criminal acts in Article 55 of the BPJS Law includes legal certainty, authority, and legal benefits. The ideal concept of conception can be arranged in the aspect of the table, from light to heavy with a certain time limit.
\end{abstract}

\section{Kata Kunci: $\quad$ Abstrak}

Kekaburan Permasalahan yang akan dikaji dalam artikel ini berkaitan dengan kekaburan Norma; UU BPJS; norma dalam Pasal 19 ayat (1) dan ayat (2) juncto Pasal 55 UU BPJS. Klasifikasi Tindak Kekaburan norma tersebut terjadi karena dianggap tidak adanya batasan Pidana. $\quad$ yang jelas mengenai unsur-unsur pelanggaran pada pasal tersebut sehingga dalam prakteknya terdapat beberapa pelanggaran keterlambatan perusahaan dalam membayar iuran BPJS. Tulisan ini akan menelaan apa sesunggunya urgensi klasifikasi tindak pidana dalam UU BPJS dan bagaimana konsep ideal klasifikasi yang seharusnya. Artikel ini menggunakan metode penelitian hukum normatif dengan pendekatan perundang-undang dan pendekatan konseptual. Adapun hasil penelitian menunjukkan bahwa urgensi diaturnya klasifikasi tindak pidana dalam Pasal 55 UU BPJS meliputi kepastian hukum, efektivitas norma dan kemanfaatan hukum. Konsep ideal klasifikasi dapat meliputi pengaturan di aspek keterlambatan, mulai dari ringan hingga berat dengan batasan waktu tertentu.

Copyright (c) 2021 Andrias Winarno, Bambang Sugiri dan Yuliati Cholil. (c)(i)(?)

Pendahuluan Published in Media Iuris. Published by Universitas Airlangga, Magister Ilmu Hukum.

Kejelasan dan ketegasan konsep tujuan negara sangat penting sebagai kunci utama dalam menerjemahkan norma hukum yang berhirarki lebih rendah ${ }^{1}$ Pemaknaan norma hukum yang berhierarki lebih rendah dilakukan dalam rangka melakukan uji ulang tingkat singkronisasi dan konsistensi terhadap konsep 
kesejahteraan sosial yang tidak memiliki rumusan akuntabel. ${ }^{2}$ Pemenuhan kesejahteraan sosial adalah tugas dan tanggung jawab negara melalu penjaminan dan pemenuhan, tetapi riwayat kenegaraan Indonesia sejak awal kemerdekaan hingga hari ini belum menunjukkan hasil yang baik Tercapainya kemakmuran dan kesejahteraan bagi seluruh rakyat Indonesia adalah salah satu cita-cita yang diinginkan oleh para pendiri negara Indonesia. Proses pembangunan yang hanya memberikan kesempatan bagi sebagian kecil kelompok masyarakat untuk menikmati hasil-hasil pembangunan dan meminggirkan kelompok masyarakat lainnya adalah pengingakaran terhadap cita-cita tadi. Para peneliti ekonomi kerakyatan berpandangan bahwa proses pembangunan ekonomi di Indonesia telah semakin menjauh dari cita-cita keadilan sosial, kemakmuran dan kesejahteraan bagi seluruh rakyat Indonesia. ${ }^{3}$

Salah satu instrumen yang dibangun pemerintah adalah dengan membangun sistem jaminan sosial dalam rangka memberikan jaminan terhadap pemenuhan hak warga negara melalui model preventif. Peserta program ini adalah tenaga kerja di sektor formal, seperti pegawai negeri atau pegawai swasta. Fokus dalam pengembangan sistem perlindungan sosial diarahkan pada jaminan sosial dengan pendanaan bersumber dari asuransi sosial, bantuan sosial dan tabungan. Tantangan utamanya adalah bagaimana mengembangkan sistem jaminan sosial yang secara cepat mencakup sebanyak- banyak warga negara dan mengefektifkan bantuan sosial agar benar-benar dapat diterima oleh warga negara yang benar-benar membutuhkannya. Pengalaman di berbagai negara menunjukkan bahwa perluasan ini memerlukan komitmen pemerintah, penegakan hukum yang konsisten, dan terdapatnya sejumlah pekerja di sektor formal yang memadai jumlahnya. ${ }^{4}$

Sistem perlindungan sosial pada akhirnya akan mendorong sebanyak mungkin warga negara yang mau dan mampu menjadi peserta jaminan sosial,

\footnotetext{
${ }^{2}$ I Gede Sanica, Paradigma Baru Akuntabilitas Keuangan: Sebuah Tinjauan Kelembagaan Organisasi Subak Jatiluwih Tabanan Bali (Pusaka Abadi 2019).[64].

${ }^{3}$ A. Alfitri, 'Ideologi Welfare State Dalam Dasar Negara Indonesia: Analisis Putusan Mahkamah Konstitusi Terkait Sistem Jaminan Sosial Nasional' (2012) 9 Jurnal Konstitusi.[72].

${ }^{4}$ Muh. Kadarisman, 'Analisis Tentang Pelaksanaan Sistem Jaminan Sosial Kesehatan Pasca Putusan Mahkamah Konstitusi No. 07/Puu-III/2005’ (2015) 22 Jurnal Hukum Ius Quia Iustum.[88].
} 
sehingga warga negara yang memperoleh bantuan sosial, masyarakat yang tidak beruntung dan rentan atau Penyandang Masalah Kesejahteraan Sosial (PMKS) dan masyarakat miskin, yang menjadi kelompok sasaran pelayanan sosial menjadi semakin kecil. Semakin banyak warga negara yang tercakup dalam skema jaminan sosial akan memperkecil kemungkinan warga negara tersebut jatuh ke jurang kemiskinan manakala pendapatannya berkurang atau hilang tiba-tiba akibat suatu penyakit, PHK, kecelakaan, pensiun, atau sebab lain. ${ }^{5}$ Banyak tantangan untuk mewujudkan sistem jaminan sosial yang efektif, mulai dari pilihan instrumen hukum yang tegas, dapat dilaksanakan, hingga jumlah populasi Indonesia yang penerimaannya harus dirasakan secara merata, karena itulah ciri-ciri negara hukum kesejahteraan menurut Muchsan yang dikutip oleh Elviandri, dkk adalah, Negara bertujuan mensejahterakan kehidupan warganya secara merata. ${ }^{6}$

Dalam Data dan Informasi Profil Kesehatan Indonesia Tahun 2017 terdapat 261.890.870 jiwa penduduk di Indonesia. ${ }^{7}$ Dengan jumlah penduduk yang cukup besar tersebut, usaha-usaha pemerintah dalam mewujudkan kesejahteraan ialah salah satunya dengan sistem jaminan sosial. Negara mengembangkan sistem jaminan sosial bagi seluruh rakyat dan memberdayakan masyarakat yang lemah dan tidak mampu sesuai dengan martabat kemanusiaan. ${ }^{8}$ Negara Indonesia menjamin dan melindungi hak-hak asasi manusia para warganya terutama dalam kaitannya dengan kesejahteraan hidupnya baik jasmaniah maupun rokhaniah. ${ }^{9}$ Adapun mendapatkan hak jaminan sosial merupakan salah satu hak asasi manusia yang dijamin oleh konstitusi, yaitu terdapat dalam Pasal 28H ayat (3) UUD NRI Tahun 1945. Jaminan sosial merupakan hak setiap orang yang pemenuhannya dijamin oleh konsti- tusi dan peraturan perundang-undangan yang berlaku.

${ }^{5}$ ibid.

${ }^{6}$ Elviandri, et.al., ‘Quo Vadis Negara Kesejahteraan: Meneguhkan Ideologi Welfare State Negara Hukum Kesejahteraan Indonesia' (2019) 31 Mimbar Hukum.[252].

${ }^{7}$ Kementerian Kesehatan Republik Indonesia, 'Data Dan Informasi Profil Kesehatan Indonesia $2017^{\prime}<$ http:/ / www.depkes.go.id/article/view/18042300004/lampiran-data-profil-kesehatan-indonesia>.

${ }^{8}$ Lihat Pasal 34 ayat (2) Undang-Undang Dasar Negara Republik Indonesia Tahun 1945.

${ }^{9}$ Kaelan, Pendidikan Pancasila Edisi Reformasi (Paradigma 2010).[221]. 
Pelaksanannya terutama dikaitkan dengan upaya pemerintah dalam pengentasan ke- miskinan, yang dilakukan secara bertahap sesuai dengan kemampuan negara, swasta dan masyarakat dalam pembiayaannya. ${ }^{10}$ Dijaminnya hak jaminan sosial sebagai hak asasi manusia, kesejahteraan rakyat diharapkan mampu diwujudkan sehingga tujuan bernegara dan berbangsa dapat diwujudkan. Hal tersebut juga bukan wacana pemerintah semata, untuk mewujudkan terpenuhinya jaminan sosial bagi rakyat Indonesia, pada tahun 2004 telah diundangkan Undang-Undang Nomor 40 Tahun 2004 tentang Sistem Jaminan Sosial Nasional (untuk selanjutnya disebut UU Sistem Jaminan Sosial Nasional).

Semangat yang dibawa UU Sistem Jaminan Sosial Nasional ialah memenuhi kebutuhan dasar hidup yang layak dan memperoleh jaminan apabila mengalami kecelakaan dan memberikan kepastian perlindungan dan kesejahteraan sosial bagi seluruh rakyat Indonesia. Melalui program ini, diharapkan setiap penduduk dapat terjamin ketika menderita sakit, kehilangan pekerjaan, dan memasuki usia lanjut atau pensiun. ${ }^{11} \mathrm{Hal}$ ini semakin mempertegas keinginan mewujudkan tujuan negara, UU Sistem Jaminan Sosial Nasional mengatur hal-hal pokok yang hendak dilakukan pemerintah dalam mewujudkan kesejahteraan yaitu meliputi Badan Penyelenggara Jaminan Sosial, Dewan Jaminan Sosial Nasional, Kepesertaan dan Iuran, Program Jaminan Sosial, sampai dengan Pengelolaan Dana Jaminan Sosial.

Jaminan Sosial juga dijamin dalam Deklarasi Perserikatan Bangsa-Bangsa tentang Hak Asasi Manusia Tahun 1948 dan juga Konvensi ILO Nomor 102 Tahun 1952 yang menganjurkan semua negara untuk memberikan perlindungan minimum kepada setiap tenaga kerja. Adapun selain dijamin di dalam konstitusi, jaminan sosial juga diatur dalam TAP MPR Nomor X/MPR/2001 yang menugaskan Presiden untuk membentuk Sistem Jaminan Sosial Nasional dalam rangka memberikan perlindungan sosial yang menyeluruh dan terpadu.

${ }^{10}$ Mujibussalim, et.al., 'Jaminan Sosial Kesehatan: Integrasi Program Jaminan Kesehatan Aceh Dalam Sistem Jaminan Sosial Nasional’ (2013) 2 Jurnal Dinamika Hukum.[229].

${ }^{11}$ Zaelani, 'Komitmen Pemeritah Dalam Penyelenggara Dalam Jaminan Sosial Nasional' (2012) 9 Jurnal Legislasi Indonesia.[191-206]. 
Adapun dalam UU Sistem Jaminan Sosial Nasional, yang dimaksud dengan Jaminan Sosial adalah salah satu bentuk perlindungan sosial untuk menjamin seluruh rakyat agar dapat memenuhi kebutuhan dasar hidupnya yang layak. ${ }^{12}$ Sistem Jaminan Sosial Nasional pada dasarnya merupakan program Negara yang bertujuan memberi kepastian perlindungan dan kesejahteraan sosial bagi seluruh rakyat Indonesia. Dalam bagian umum penjelasan UU Sistem Jaminan Sosial Nasional, Indonesia dalam beberapa dekade terakhir telah menjalankan beberapa program jaminan sosial. ${ }^{13}$ Program tersebut antara lain meliputi Jaminan Sosial Tenaga Kerja (Jamsostek) melalui Undang-Undang Nomor 3 Tahun 1992, yang mencakup program jaminan pemeliharaan kesehatan, jaminan kecelakaan kerja, jaminan hari tua dan jaminan kematian.

Berdasarkan hal tersebut UUSistem Jaminan Sosial Nasional perlu diaplikasikan dengan baik agar mampu mensinkronisasikan program-program jaminan sosial yang dilaksanakan oleh berbagai penyelenggara agar dapat menjangkau kepesertaan yang lebih luas serta memberikan manfaat yang lebih besar bagi setiap peserta. ${ }^{14}$

Pada tahun 2011 disahkan Undang-Undang Nomor 24 Tahun 2011 tentang Badan Penyelenggara Jaminan Sosial (BPJS) (untuk selanjutnya disebut UU BPJS). Hal tersebut sebagai tindak lanjut pelaksanaan sistem jaminan sosial nasional diamanatkan dalam konstitusi, Tap MPR dan UU Sistem Jaminan Sosial Nasional. Pasal 5 ayat (1) UU Sistem Jaminan Sosial Nasional menentukan bahwa Badan Penyelenggara Jaminan Sosial harus dibentuk dengan Undang-Undang, selanjutnya ditetapkan UU BPJS. ${ }^{15}$ Seperti halnya diatur dalam UU Sistem Jaminan Sosial Nasioal, dalam UU BPJS memberikan pengertian mengenai Badan Penyelenggara Jaminan Sosial (BPJS) merupakan badan hukum yang dibentuk untuk menyelenggarakan program jaminan sosial. Nasional.

${ }^{12}$ Lihat Pasal 1 angka 1 Undang-Undang Nomor 40 Tahun 2004 tentang Sistem Jaminan Sosial

${ }^{13}$ Lihat bagian Umum Penjelasan Undang-Undang Nomor 40 Tahun 2004 tentang Sistem Jaminan Sosial Nasional.

14 ibid.

${ }^{15}$ Hariyanto, 'Ketua DJSN: Hingga Tahun Ke-5, Implementasi UU SJSN Diwarnai Berbagai Dinamika Yang Berkembang, <http://www.industry.co.id/read/39258/ketua-djsn-hingga-tahunke-5-implementasi-uu-sjsn-diwarnai -berbagai-dinamika-yang-berkembang.html>. 
BPJS dibentuk berdasarkan prinsip kegotongroyongan, nirlaba, keterbukaan, kehati-hatian, akuntabilitas, portabilitas, kepesertaan bersifat wajib, dana amanat, dan Dana Jaminan Sosial dipergunakan seluruhnya untuk pemngembangan program dan untuk sebesar-besarnya kepentingan perserta dalam hal ini ialah rakyat Indonesia. UU BPJS membentuk dua BPJS, antara lain BPJS Kesehatan dan BPJS Ketenagakerjaan. Masing-masing untuk BPJS Kesehatan menyelenggarakan program jaminan kesehatan dan BPJS Ketenagakerjaan menyelenggarakan program jaminan kecelakaan kerja, jaminan hari tua, jaminan pensiun dan jaminan kematian.

Implementasi program-program jaminan sosial di BPJS Kesehatan dan BPJS Ketenagakerjaan mengalami dinamika yang beragam. Seperti halnya dalam BPJS Kesehatan antusias masyarakat meningkat dalam mengakses layanan kesehatan. Sebagai contoh total dana yang dikeluarkan BPJS Kesehatan untuk pelayanan di Fasilitas Kesehatan Tingkat Pertama dan Fasilitas Kesehatan Tingkat Lanjutan pada tahun 2016 mencapai Rp. 79 Triliun, pada tahun 2017 meningkat menjadi Rp. 96,7 triliun. $^{16}$

Implementasi Jaminan Sosial Ketenagakerjaan menyisakan sejumlah permasalahan, antara lain target kepesertaan Jaminan Sosial Ketenagakerjaan yang ditetapkan dalam Peta Jalan pada Tahun 2017 adalah sebanyak 53.325.698 jiwa, namun dalam realisasinya sampai dengan bulan Juni 2018 baru mencapai 27.999.455 jiwa. ${ }^{17}$ Angka ini baru mencapai 47,5 \% dari target yang ditetapkan dalam Peta Jalan.

Menurut Molengraff, pengertian perusahaan dari sudut ekonomi adalah keseluruhan perbuatan yang dilakukan secara terus menerus, bertindak keluar, untuk memperoleh penghasilan, dengan cara memperdagangkan atau menyerahkan barang atau mengadakan perjanjian perdagangan. ${ }^{18}$ Perusahaan dalam UU BPJS termasuk dalam pengertian Pemberi Kerja, adapun Pemberi Kerja

\footnotetext{
${ }^{16}$ ibid.

17 ibid.

${ }^{18}$ Abdulkadir Muhammad, Hukum Perusahaan Indonesia (Citra Aditya Bhakti 2006).[7].
} 
ialah orang perseorangan, pengusaha, badan hukum, atau badan lainnya yang memperkerjakan tenaga kerja atau penyelenggara negara yang mempekerjakan pegawai negeri dengan membayar gaji, upah, atau imbalan dalam bentuk lainnya. ${ }^{19}$

Perusahaan sebagai pemberi kerja secara bertahap wajib mendaftarkan dirinya dan pekerjanya sebagai peserta kepada BPJS sesuai dengan Program Jaminan Sosial yang diikuti. Berdasarkan Pasal 17 UU BPJS, perusahaan yang tidak mendaftarkan dirinya dan pekerjanya akan dikenakan sanksi administratif antara lain teguran tertulis, denda dan/atau tidak mendapat pelayanan tertentu.

Diterapkannya sanksi administratif kepada perusahaan yang tidak mendaftarkan dalam BPJS dikarenakan tidak efektifnya pencantuman sanksi pidana pada peraturan sebelumnya, tujuan pencantuman yang harapannya untuk memberikan perlindungan hukum kepada pekerja, justru mengancam keberlangsungan hubungan kerja antara pekerja dengan perusahaan. ${ }^{20}$ Penghapusan sanksi pidana sesuai dengan tujuan penyelenggaraan jaminan sosial, yaitu untuk mendapatkan kepesertaan yang sebanyak-banyaknya sebagai wujud dari hak konstitusional warga Negara. ${ }^{21}$

Perusahaan yang telah menjadi peserta BPJS, berdasarkan Pasal 19 ayat (1) dan ayat (2) UU BPJS, perusahaan berkewajiban untuk: "Pemberi Kerja wajib memungut iuran yang menjadi beban Peserta dari Pekerjanya dan menyetorkannya kepada BPJS." Dalam yyat (2) disebutkan bahwa Pemberi Kerja wajib membayar dan menyetor Iuran yang menjadi tanggung jawabnya kepada BPJS.

Dari kedua pasal tersebut perusahaan yang sudah menjadi peserta BPJS wajib untuk memungut iuran, membayar dan menyetor iuran yang menjadi beban peserta dari pekerjanya kepada BPJS. Dalam UU BPJS memberikan sanksi pidana bagi perusahaan yang melanggar Pasal 19 ayat (1) dan ayat (2) yang diatur dalam Pasal 55 UU BPJS. Adapun bunyi pasal 55 UU BPJS antara lain:

\footnotetext{
${ }^{19}$ Pasal 1 angka 9 Undang-Undang Nomor 24 Tahun 2011 tentang Badan Penyelenggara Jaminan Sosial.

${ }^{20}$ Ratih Dheviana Puru Hitaningtyas, 'Penghapusan Sanksi Pidana Terkait Kewajiban Pemberi Kerja Untuk Mengikutsertakan Pekerjanya Dalam Program Jaminan Sosial' (2017) 2 Jurnal Panorama Hukum.[51].

${ }^{21}$ ibid.
} 
"Pemberi Kerja yang melanggar ketentuan sebagaimana dimaksud dalam Pasal 19 ayat (1) atau ayat (2) dipidana dengan pidana penjara paling lama 8 (delapan) tahun atau pidana denda paling banyak Rp. 1.000.000.000,00 (satu miliar rupiah)."

Terlihat bahwa UU BPJS sangat ketat dalam menertibkan perusahaan untuk melaksanakan Pasal 19 ayat (1) dan ayat (2) yang menjadi kewajibannya setelah menjadi peserta BPJS. Namun, dari konstruksi dalam Pasal 19 ayat (1) dan ayat (2) jo. Pasal 55 UU BPJS terdapat kekaburan norma (vague norm). Kekaburan norma adalah kondisi dimana suatu kata atau kalimat di dalam perundang-undangan tidak mempunyai arti yang tepat dan karena itu tidak dapat dijadikan suatu dasar hukum/ hukum itu tidak bisa diterapkan. ${ }^{22}$ Kekaburan norma tersebut, menyebabkan penegak hukum/institusi terkait di lapangan memiliki tafsir yang berbeda. ${ }^{23}$ Dalam hal ini ialah tidak adanya batasan yang jelas mengenai unsur pelanggaran pasal tersebut. Dalam pasal tersebut, tidak ditegaskan mengenai tolak ukur keterlambatan, ukuran tersebut tidak ada dalam unsur-unsur pasal tersebut, padahal hal ini diperlukan karena norma ini adalah norma yang menggunakan sanksi pidana, maka secara mutatis mutandis, keberadaan norma ini juga merupakan norma pidana yang mengharuskan adanya unsur yang tegas dan jelas. Unsur-unsur tindak pidana adalah merupakan indikator atau tolok ukur dalam memutuskan apakah perbuatan seseorang dapat dikualifikasikan sebagai tindak pidana atau tidak. ${ }^{24}$

Dalam praktiknya kemudian terdapat beberapa pelanggaran diantaranya keterlambatan membayar iuran BPJS. Sehingga, penulis melihat adanya kekaburan norma terkait pembayaran iuran BPJS, apakah perusahaan yang melanggar Pasal 19 ayat (1) dan ayat (2) jo. Pasal 55 UU BPJS mempunyai akibat sama dengan pelanggar yang berbeda jangka waktu keterlambatan bayarnya. Atau semua pelanggar sama tidak dilihat dari jangka waktu pelanggarannya melainkan pemenuhan unsur pidana dalam pasal-pasal tersebut.

${ }^{22}$ Ni Luh et al., 'Logika Hukum Dan Terobosan Hukum Melalui Legal Reasoning' (2016) 31 Jurnal Hukum Jatiswara.[99-110].

${ }^{23}$ Mashendra, 'Perampasan Aset Korupsi Dalam Upaya Pemberantasan Tindak Pidana Korupsi Menurut Hukum Pidana Indonesia' (2020) 8 Jurnal Petitum.[21].

${ }^{24}$ Septa Candra, 'Perumusan Ketentuan Pidana Dalam Peraturan Perundang-Undangan Di Indonesia' (2013) 3 Jurnal Hukum Prioris.[111]. 


\section{Metode Penelitian}

Penelitian ini merupakan penelitian hukum normatif. Penelitian hukum normatif merupakan penelitian yang difokuskan untuk mengkaji kaidah atau norma pada hukum positif. ${ }^{25}$ Dalam penelitian ini, penulis menganalisis konstruksi dalam Pasal 19 ayat (1) dan ayat (2) jo. Pasal 55 UU BPJS terdapat kekaburan norma (vague norm). Penulis melihat adanya kekaburan norma terkait pembayaran iuran BPJS, apakah perusahaan yang melanggar Pasal 19 ayat (1) dan ayat (2) jo. Pasal 55 UU BPJS mempunyai akibat sama dengan pelanggar yang berbeda jangka waktu keterlambatan bayarnya. Atau semua pelanggar sama tidak dilihat dari jangka waktu pelanggarannya melainkan pemenuhan unsur pidana dalam pasal-pasal tersebut. Dari uraian diatas dua rumusan masalah yang akan dianalisa yaitu : apa urgensi pengaturan Klasifikasi Tindak Pidana dalam pasal 55 Undang-Undang No. 24 tahun 2011 tentang Badan Penyelenggara Jaminan Sosial (BPJS).

Penelitian ini merupakan penelitian hukum normative. Penelitian hukum normative merupakan penelitian yang difokuskan untuk mengkaji kaidah atau norma pada hukum positif. Dalam penelitian ini penulis menganalisis kontruksi dalam Pasal 19 ayat ( 1 ) dan ayat ( 2 ) jo. Pasal 55 UU BPJS terdapat kekaburan norma ( vague norm ). Penulis melihat adanya kekaburan norma terkait pembayaran iuran BPJS, apakah perusahaan yang melanggar Pasal 19 ayat ( 1 ) dan ayat ( 2 ) jo. Pasal 55 BPJS mempunyai akibat yang sama dengan pelanggar yang berbeda jangka waktu keterlambatan bayarnya. Atau semua pelanggar sama tidak dilihat dari jangka waktu pelanggaranya melainkan pemenuhan unsur pidana dalam dalam pasal-pasal tersebut. Sehingga dalam penelitian ini akan mengkaji dan menguraikan permasalahan meliputi urgensi pengaturan Klasifikasi Tindak Pidana Dalam Pasal 55 Undang-Undang No.24 Tahun 2011 tentang BPJS dan bentuk pengaturan Klasifikasi Tindak Pidana Dalam Pasal 55 Undang-Undang No. 24 Tahun 2011 tentang BPJS dimasa yang akan dating. Pendekatan dalam penelitian ini ialah pendekatan peraturan perundang-

\footnotetext{
${ }^{25}$ Johny Ibrahim, Teori dan Metodologi Penelitian Hukum Normatif (Bayumedia 2011).[295].
} 
Andrias Winarno, dkk: Kekaburan Norma dalam...

undangan (statue approach) dan pendekatan konseptual (conseptual apporoach). Metode interprestasi yang digunakan dalam penelitian ini yaitu: interprestasi gramatikal; interprestasi sistematik; interprestasi futuristik.

\section{Kekaburan Norma Pasal 19 jo. 55 UU BPJS}

Keberadaan Pasal 19 jo. 55 UU BPJS yang menggunakan insturmen sanksi pidana memiliki beberapa implikasi. Oleh karena Pasal 19 jo. 55 UU BPJS menggunakan sanksi pidana, maka norma tersebut harus tunduk dan patuh terhadap kaidah-kaidah dan asas-asas dalam hukum pidana, meskipun diketahui bersama bahwa UU BPJS bukanlah undang-undang dengan kategori pidana khusus $^{26}{ }^{26}$ arena nantinya penegakan norma tersebut juga salah satunya akan menggunakan instrumen hukum acara pidana yang yang juga merupakan bagian dari penegakan hukum pidana, sehingga penerapannya harus didasarkan pada kehati-hatian. Dapat dikatakan juga, bahwa keberadaan Pasal 19 jo. 55 UU BPJS adalah hukum pidana materil, Tirtaamidjaja menjelaskan pidana materiil adalah adalah kumpulan aturan hukum yang menentukan pelanggaran pidana; menetapkan syarat-syarat bagi pelanggaran pidana untuk dapat dihukum; menunjukkan orang yang dapat dihukum dan menetapkan hukuman atas pelanggaran pidana. $^{27}$

Hamel menyatakan hukum pidana materiil berisi asas-asas dan peraturanperaturan yang mengaitkan pelanggaran hukum dengan hukuman. Yang termasuk dalam hukum pidana materiil adalah semua ketentuan dan peraturan yang menunjukkan tentang adanya tindakan-tindakan yang merupakan tindakan

\footnotetext{
${ }^{26}$ Hukum Pidana khusus adalah mempelajari suatu hukum dibidang pidana yang pada umumnya berada ketentuannya diatur diluar KUHP yang berhubungan dengan hukum pidana umum. Pidana umum dan penyimpangan-penyimpangan yang ada terhadap hukum pidana umum dalam bentuk serta lembaga yang berwenang mengadilinya. Bisa saja ketentuan-ketentuan itu ditemukan dalam KUHD tapi karena lemahnya ketentuan-ketentuan yang ada dalam KUHP tersebut maka oleh yang berwenang dikeluarkan atau dibuat sendiri ketentuan diluar KUHP. Tujuan dari pidana khusus adalah membahas bentuk-bentuk hukum pidana yang tergolong kedalam hukum pidana khusus : Latar belakang munculnya tindak pidana khusus: 1. Karena dalam kenyataan sehari-hari banyak ditemukan delik-delik yang tidak diatur dalam KUHP. 2. Adanya delik yaitu pidananya relatif ringan, sedangkan delik itu pada waktu sekarang mempunyai dampak yang besar I Gusti Ngurah Parwata, "Mata Kuliah Tindak Pidana Khusus," <https://Simdos.Unud.Ac.Id/>.

${ }_{27}$ Tirtaamidjaja, Pokok-Pokok Hukum Pidana, (Fasco 1955). [14].
} 
yang dapat dihukum dan bisa dipertanggungjawabkan. ${ }^{28}$ Dipertegas oleh pendapat dari Simon yang menyatakan bahwa hukum pidana materiil memuat ketentuan-ketentuan dan rumusan-rumusan dari suatu tindak pidana, peraturanperaturan mengenai syarat mengenai seseorang dapat dihukum, penunjukan dari orang yang dapat dijatuhi hukuman karena perbuatannya sendiri, tentang siapa yang dapat dihukum dan bagaimana hukum tersebut dapat dijatuhkan. ${ }^{29}$

Salah satu asas yang penting dibahas berkaitan dengan kepastian hukum khususnya mengeneai lex stricta yang merupakan satu dari sekian bentuk dari asas legalitas, yang mengharuskan norma pidana tersebut dinyatakan secara tegas dan ketat. Maksud dari kepastian hukum adalah bahwa hukum yang dibuat lex scripta (harus tertulis), lex certa (tidak multitafsir) dan harus ditafsirkan lex stricta (secara ketat). Kata lain, secara formil sebuah ketentuan perundang-undangan haruslah dituangkan dalam bentuk tertulis secara sistematis yang dapat ditafsirkan secara ketat dan tidak multitafsir. Marjanne berpendapat bahwa secara khusus pandangan bahwa lex scripta itu jelas dan pasti, dalam konteks tertentu tidak ambigu, tidak dapat dipertahankan. ${ }^{30}$

Dalam suatu rumusan norma yang merupakan kebijakan harus memiliki kriteria wajib yang salah satunya adalah tercantum secara jelas dan tegas sehingga ia dapat dilaksanakan dan tidak menimbulkan kekaburan hukum/vague norm. Dalam norma pasal 19 ayat 1 dan 2 tidak memenuhi kriteria rumusan yang jelas, tegas dan tidak implementatif karena tidak terdapatnya 'jangka waktu' kapan suatu subjek hukum dalam pasal 19 itu dikatakan sudah melakukan tindak pidana. Dalam pasal 19 ayat 1 hanya mengatakan: Pemberi Kerja wajib memungut iuran yang menjadi beban Peserta dari Pekerjanya dan menyetorkannya kepada BPJS. Yang menjadi pertanyaan adalah, kapan durasi jangka waktu penyetorannya dan kapan perbuatan ini baru dapat dikatakan tindak pidana karena korporasi tidak melakukan kewajiban, apakah harus menunggu ada laporan tidak melaksanakan

\footnotetext{
${ }^{28}$ Leden Marpaung, Asas - Teori - Praktik Hukum Pidana (Sinar Grafika 2008).[3].

${ }^{29}$ P.A.F. Lamintang, Dasar-Dasar Hukum Pidana Indonesia (Sinar Baru 1990).[10-11].

${ }^{30}$ Aris Hardinanto, 'Manfaat Analogi Dalam Hukum Pidana Untuk Mengatasi Kejahatan Yang Mengalami Modernisasi'(2016) 31 Jurnal Yuridika.
} 
Andrias Winarno, dkk: Kekaburan Norma dalam...

kewajiban, atau dibutuhkan durasi waktu tertentu? Dalam pasal 19 ayat (2) juga tidak ada yang menjelaskan demikian, dimana dalam pasal itu hanya penegasan yakni "Pemberi Kerja wajib membayar dan menyetor Iuran yang menjadi tanggung jawabnya kepada BPJS". Jika dijabarkan, maka unsur dari pasal tersebut adalah:

1. Pemberi kerja; ${ }^{31}$

2. Kewajiban memungut iuran yang menjadi beban peserta;

3. Menyetorkannya kepada BPJS.

\begin{tabular}{|c|c|c|}
\hline Pasal 19 ayat (1) & Pasal 19 ayat (2) & Pasal 55 UU \\
\hline $\begin{array}{l}\text { Pemberi Kerja wajib } \\
\text { memungut iuran yang } \\
\text { menjadi beban Peser- } \\
\text { ta dari Pekerjanya dan } \\
\text { menyetorkannya kepa- } \\
\text { da BPJS. }\end{array}$ & $\begin{array}{l}\text { Pemberi Kerja wa- } \\
\text { jib membayar dan } \\
\text { menyetor Iuran yang } \\
\text { menjadi tanggung } \\
\text { jawabnya kepada } \\
\text { BPJS. }\end{array}$ & $\begin{array}{l}\text { Pemberi Kerja yang me- } \\
\text { langgar ketentuan se- } \\
\text { bagaimana dimaksud } \\
\text { dalam Pasal } 19 \text { ayat (1) } \\
\text { atau ayat (2) dipidana } \\
\text { dengan pidana penjara } \\
\text { paling lama } 8 \text { (delapan) } \\
\text { tahun atau pidana den- } \\
\text { da paling banyak Rp. } \\
\text { 1.000.000.000,00 (satu } \\
\text { miliar rupiah). }\end{array}$ \\
\hline
\end{tabular}

Pasal 19 UU BPJS adalah norma yang kabur, karena tidak mengatur secara terang mengenai unsur-unsur perbuatan pidana/bestandel delict, khususnya mengenai kriteria waktu kapan pemberi kerja dinyatakan tidak memenuhi kewajiban, sebagaimana tercantum dalam rumusan frasa Kewajiban memungut iuran yang menjadi beban peserta. Hal-hal ini tidak ada dalam UU BPJS, akan tetapi unsur-unsur tersebut ada dalam beberapa peraturan pelaksana, salah satunya PP No. 86 Tahun 2013 Tentang Tata Cara Pengenaan Sanksi Administratif Kepada Pemberi Kerja Selain Penyelenggara Negara Dan Setiap Orang, Selain Pemberi Kerja, Pekerja, Dan Penerima Bantuan Iuran Dalam Penyelenggaraan Jaminan Sosial. Dengan pendekatan PP tersebut, baru kita dapat melihat kapan dan bagaimana mengenai unsur pidana dimana pemberi kerja 'dapat' dikatakan

${ }^{31}$ Lihat dalam pasal 1 ayat (9) UU BPJS: Pemberi Kerja adalah orang perseorangan, pengusaha, badan hukum, atau badan lainnya yang mempekerjakan tenaga kerja atau penyelenggara negara yang mempekerjakan pegawai negeri dengan membayar gaji, upah, atau imbalan dalam bentuk lainnya. 
tidak melakukan kewajiban. Hal ini tentu bertentangan dengan prinsip hukum pidana, dimana dijelaskan bahwa unsur-unsur pidana harus ditegaskan secara tegas terang benderang/expresis verbis dalam undang-undang, bukan dalam peraturan pelaksana. ${ }^{32}$

Dalam pasal 55 tercantum frasa 'Pemberi Kerja yang melanggar', apa yang disebut dengan kriteria melanggar? Dan kapan suatu perbuatan disebut sebagai perbuatan yang dilarang/strafbaar yang dilakukan oleh pemberi kerja sebagai subjek tindak pidana/addressaat norm. Hemat penulis, norma dalam pasal 55 ini tidak memenuhi kelengkapan rumusan pidana yang terdiri dari unsur-unsurnya/ bestandel delict sehingga saat diterapkan, akan kesulitan kapan dan berapa jangka waktu pemberi kerja telah melakukan tindak pidana berupa pengabaian kewajiban yang dicantumkan dalam pasal 19. Hal itu harus dicantumkan secara expresis verbis dalam undang-undang dan tidak boleh diatur lebih lanjut dalam peraturan pelaksana, karena merupakan ketentuan mengenai norma pidana. ${ }^{33}$

Hukum di Indonesia pada perkembangannya saat ini dirasakan bergerak secara dinamis seiring berjalannya waktu dan hal ini dipengaruhi oleh semakin pesat perkembangan sosial. Karena itu banyak masyarakat sekarang menuntut serta mengharuskan hukum dapat bergerak semakin maju untuk dapat menjadi pengendali dari setiap permasalahan sosial sehingga terciptanya kesejahteraan. Untuk itu hukum di Indonesia harus dapat selaras dan berjalan dengan baik melalui aturan-aturan hukum. Alasan tersebut yang membuat hukum di Indonesia bersifat tertulis diharapkan agar setiap lapisan masyarakat dapat mengerti dan menaati hukum positif tersebut. Doktrin menjelaskan bahwa hukum pidana di Indonesia yang dibuat secara tertulis terbagi menjadi 2 (dua) bagian yaitu hukum pidana materiil dan hukum pidana formil. Hukum pidana materiil adalah tata cara mengadili atau proses mengadili terhadap pelanggaran yang dilakukan oleh seseorang sesuai dengan tata tertib yang telah diatur dalam rangka

\footnotetext{
${ }^{32}$ Barda Nawawi Arif, Bunga Rampai Hukum Pidana (Citra Aditya Bhakti 1996).[256].

${ }^{33}$ Septa Candra, 'Perumusan Ketentuan Pidana Dalam Peraturan Perundang-Undangan di Indonesia' (2013) 3 Jurnal Hukum Prioris.
} 
mempertahankan hukum pidana materiil atau dapat disebut juga hukum yang mengatur cara bagaimana hukum pidana materiil diwujudkan sehingga diperoleh keputusan hakim,9 hukum untuk mencari kebenaran fundamental. Seperti yang diungkapkan oleh Andi Hamzah bahwa tujuan dari hukum pidana formil adalah untuk mencari dan mendapatkan atau setidak - tidaknya mendekati kebenaran materiil, yaitu kebenaran yang selengkap - lengkapnya. ${ }^{34}$

Dengan tidak tercantumnya Pasal 19 jo. 55 UU BPJS dengan tegas, maka itu berhaluan dari spirit kepastian hukum yang merupakan tujuan dari adanya asas legalitas. Rumusan Asas legalitas adalah asas yang paling penting dalam hukum pidana, bahkan dianggap roh hukum pidana. Penyempitan ruang lingkup asas legalitas seperti ini, sesungguhnya tidak tepat karena asas ini juga berlaku dalam ranah hukum pada umumnya. Tentu saja, perluasan ruang lingkup asas ini membawa konsekuensi pada perbedaan makna legalitas itu sendiri. Lon L. Fuller, misalnya, dalam bukunya The Morality of Law (1964), menggunakan kata "principle of legality" untuk memaknai prinsip hukum secara umum, yang bahkan disebutnya sebagai inner morality of law. Kata 'principle' dalam konteks ini diartikan sama dengan prinsip atau asas. Fuller menyebutkan delapan asas legalitas itu, yang diringkas menjadi delapan pernyataan sebagai berikut: (1) laws should be general; (2) they should be promulgated, that citizens might know the standards to which they are being held; (3) retroactive rule-making and application should be minimized; (4) laws should be understandable; (5) they should not be contradictory; (6) laws should not require conduct beyond the abilities of those affected; (7) they should remain relatively constant through time; dan (8) there should be a congruence between the laws as announced and their actual administration. Di sini Fuller memaknai asas legalitas sebagai moralitas hukum internal karena ia meyakini asas ini sebagai bagian terpenting dalam moralitas kewajiban (dilawankannya dengan moralitas aspirasi). Moralitas kewajiban itulah yang menjadi sumber bagi pembentukan

${ }^{34}$ Andi Hamzah, Asas-Asas Hukum Pidana (Rineka Cipta 2010).[7]. 
norma hukum. Hukum adalah "A particular way of achieving social order by guiding human behavior according to rules." Moralitas yang terdalam terletak justru pada "universal procedural norms". Jadi, delapan asas legalitas tersebut sesungguhnya merupakan delapan asas universal dalam hukum acara. ${ }^{35}$

\section{Urgensi Pengaturan Klasifikasi Tindak Pidana dalam Pasal 55 Undang-Undang Nomor 24 Tahun 2011 tentang BPJS}

Teori Kepastian Hukum Hans Kelsen berpendapat bahwa hukum merupakan sebuah sistim norma yang terukur. ${ }^{36}$ Norma yaitu pernyataan yang menekankan aspek das solllen (seharusnya) dengan menyertakan beberapa peraturan-peraturan tentang apa yang harus dilakukan (das sein). Norma adalah produk dan aksi manusia yang deliberatif. Undang-undang yang berisikan berbagai aturan yang bersifat umum dan menjadi pedoman bagi manusia/individu bertingkah laku dalam masyarakat, baik dalam hubungannya dengan sesama individu, maupun dalam hubungan dengan masyarakat. Aturan-aturan tersebut menjadi batasan dalam membebani ataupun melakukan tindakan terhadap individu. Adanya aturan tersebut dan pelaksanaan aturan itu menimbulkan suatu kepatian hukum. Teori kepastian hukum mengandung dua pengertian yakni: ${ }^{37}$

a. Adanya aturan yang bersifat umum membuat individu mengetahui perbuatan apa yang boleh atau yang tidak boleh dilakukan;

b. Keamanan hukum bagi individu dari kesewenangan pemerintah karena dengan adanya aturan hukum yang bersifat umum itu individu dapat mengetahui apa saja yang boleh dibebankan atau dilakukan oleh Negara terhadap individu.

\footnotetext{
${ }^{35}$ Shidarta, 'Asas Legalitas' <https://business-law.binus.ac.id/2016/02/02/asas-legalitas/>.

${ }^{36}$ Mario Julyano and Aditya Yuli Sulistyawan, 'Pemahaman Terhadap Asas Kepastian Hukum Melalui Konstruksi Penalaran Positivisme Hukum' (2019) 1 Jurnal Crepido.[13-22according to Gustav Radbruch, is included in the basic legal value. This principle basically expects and requires the law to be made definitively in written form. The existence of this principle is important because it will guarantee the clarity of a positive legal product that exists. The important meaning of this principle also has a similarity (similarity].

${ }^{37}$ Peter Mahmud Marzuki, Pengantar Ilmu Hukum (Kencana Press 2008).[158].
} 
Menurut Satjipta Raharjo, kepastian hukum memiliki empat makna: pertama, bahwa hukum itu positif artinya bahwa ia adalah perundanganundangan (Gesetliches Recht), hukum itu didasarkan pada fakta (Tatsachen) bukan suatu rumusan tentang penilaian yang nanti, fakta harus dirumuskan dengan cara yang jelas sehingga menghidari kekeliruan dan pemaknaan, dan hukum positif itu tidak boleh sering diubah-ubah. ${ }^{38}$ Dari empat makna tersebut maka dapat diketahui bahwa hukum harus dirumuskan dengan cara yang jelas untuk menghindari kekeliruan dalam pemaknaan, pada saat yang sama hukum tersebut juga mudah untuk dijalankan.

MenurutFernando MManullang, Kepastian hukum merupakan pelaksanaan hukum sesuai dengan bunyinya sehingga masyarakat dapat memastikan bahwa hukum dilaksanakan. Dalam memahami nilai kepastian hukum yang harus diperhatikan adalah bahwa nilai itu mempunyai relasi yang erat dengan instrumen hukum yang positif dan peranan negara dalam mengaktualisasikannya pada hukum positif. ${ }^{39}$

Dari uraian-uraian mengenai kepastian hukum di atas, maka kepastian dapat mengandung beberapa arti, yakni adanya kejelasan, tidak menimbulkan multitafsir, tidak menimbulkan kontradiktif, dan dapat dilaksanakan. Hukum harus berlaku tegas di dalam masyarakat, mengandung keterbukaan sehingga siapapun dapat memahami makna atas suatu ketentuan hukum. Hukum yang satu dengan yang lain tidak boleh kontradiktif sehingga tidak menjadi sumber keraguan. Kepastian hukum menjadi perangkat hukum suatu negara yang mengandung kejelasan, tidak menimbulkan multitafsir, tidak menimbulkan kontradiktif, serta dapat dilaksanakan, yang mampu menjamin hak dan kewajiban setiap warga negara sesuai dengan budaya masyarakat yang ada.

Pelanggaran dalam Tindak pidana merupakan perbuatan yang dilakukan oleh seseorang/badan hukum dengan melakukan suatu kejahatan atau

\footnotetext{
${ }^{38}$ Satjipto Rahardjo, Hukum Dalam Jagat Ketertiban (UKI Press 2006).[135-136].

${ }^{39}$ E. Fernando M. Manullang, 'Sesat Pikir Aplikasi Hermeneutika Hukum Menurut HansGeorg Gadamer' (2018) 48 Jurnal Hukum \& Pembangunan.[393].
} 
pelanggaran pidana yang merugikan kepentingan orang lain atau merugikan kepentingan umum. Sifat jahat dari tidak dilakukannya kewajiban perusahaan sebagaimana tertera dalam paal 19 adalah menghambat pencapaian target jaminan sosial. Menurut Vos, tindak pidana adalah suatu kelakuan manusia diancam pidana oleh peraturan-peraturan undang-undang, jadi suatu kelakuan pada umumnya dilarang dengan ancaman pidana. ${ }^{40}$ Perbuatan pidana adalah perbuatan seseorang atau sekelompok orang yang menimbulkan peristiwa pidana atau perbuatan melanggar hukum pidana dan diancam dengan hukuman. Berdasarkan pendapat mengenai pengertian tindak pidana dapat diketahui unsurunsur tindak pidana adalah harus ada sesuatu kelakuan (gedraging), kelakuan itu harus sesuai dengan uraian undang-undang (wettelijke omschrijving), kelakuan itu adalah kelakuan tanpa hak, kelakuan itu dapat diberatkan kepada pelaku, dan kelakuan itu diancam dengan hukuman. ${ }^{41}$

UU BPJS selain merupakan undang-undang yang mengatur pembentukan sebuah lembaga penyelenggara jaminan sosial nasional, juga mengatur mengenai ketentuan pidana bagi pelanggar UU BPJS. Ketentuan pidana diatur dalam BAB XV terdiri dari 2 (dua) pasal yaitu Pasal 54 dan Pasal 55:

Pasal 54

“Anggota Dewan Pengawas atau anggota Direksi yang melanggar larangan ketentuan sebagaimana dimaksud dalam Pasal 52 huruf g, huruf h, huruf i, huruf $j$, huruf $k$, huruf 1 , atau huruf $m$ dipidana dengan pidana penjara paling lama 8 (delapan) tahun dan pidana denda paling banyak Rp1.000.000.000,00 (satu miliar rupiah)".

\section{Pasal 55}

“Pemberi Kerja yang melanggar ketentuan sebagaimana dimaksud dalam Pasal 19 ayat (1) atau ayat (2) dipidana dengan pidana penjara paling lama 8 (delapan) tahun atau pidana denda paling banyak Rp1.000.000.000,00 (satu miliar rupiah)".

${ }^{40}$ Tri Andrisman, Hukum Pidana (Asas-Asas Dan Dasar Aturan Umum Hukum Pidana Indonesia) (Universitas Lampung Press 2009).

${ }^{41}$ Erwin Sitompul, Bruce Anzward, and Galuh Praharafi, 'Kekerasan Legal Liability Against Victims Of Self-Defense Resulting In Death Of Criminal Theft With Violence Artikel' (2020) 2 Jurnal Lex Suprema.[516]. 
Produk undang-undang yang memuat "ketentuan pidana" pada hakikatnya dapat dikualifikasikan sebagai undang-undang pidana khusus. Hal tersebut sebagaimana dikemukakan oleh Sudarto bahwa undang-undang pidana khusus merupakan undang- undang pidana selain Kitab UndangUndang Hukum Pidana (KUHP) yang merupakan induk peraturan hukum pidana. ${ }^{42}$ Upaya penanggulangan tindak pidana dengan menggunakan sanksi pidana pada hakikatnya merupakan cara yang paling tua, setua peradaban manusia itu sendiri. Namun demikian, penggunaan sanksi pidana ternyata masih diandalkan sebagai sarana penanggulangan tindak pidana. Hal tersebut dapat diketahui dari kebanyakan produk undang-undang dewasa ini yang hampir selalu mencantumkan bab mengenai "ketentuan pidana". Dalam kerangka demikian, seolah-olah dirasakan kurang sempurna atau "hambar" apabila suatu produk undang-undang atau disajikan tanpa ketentuan pidana. Pencantuman bab "ketentuan pidana" tersebut bahkan terkadang dilatarbelakangi oleh suatu sikap atau asumsi bahwa "kurang aman" atau "kurang ada jaminan" apabila suatu produk undang-undang tidak ada ketentuan pidananya. ${ }^{43}$

Dua pasal di atas mengatur ketentuan pidana bagi pelanggar yang berbeda, dalam Pasal 54 berlaku bagi Anggota Dewan Pengawas atau anggota direksi BPJS baik BPJS Kesehatan maupun BPJS Ketenagakerjaan. Sedangkan dalam Pasal 55 berlaku bagi perusahaan yang melanggar ketentuan dalam Pasal 19 ayat (1) dan ayat (2), yang berbunyi:

Pasal 19 ayat (1)

“Pemberi Kerja wajib memungut iuran yang menjadi beban Peserta dari Pekerjanya dan menyetorkannya kepada BPJS".

Pasal 19 ayat (2)

“Pemberi Kerja wajib membayar dan menyetor Iuran yang menjadi tanggung jawabnya kepada BPJS".

\footnotetext{
${ }^{42}$ Supriyadi, 'Penetapan Tindak Pidana Sebagai Kejahatan Dan Pelanggaran Dalam UndangUndang Pidana Khusus’ (2016) 27 Mimbar Hukum.[389].

${ }^{43}$ ibid.
} 
Ketentuan tersebut mewajibkan kepada perusahaan untuk memungut iuran yang menjadi beban peserta dari pekerjanya dan menyetorkannya kepada BPJS, sedangkan kewajiban kedua ialah membayar dan menyetor iuran yang menjadi tanggung jawabnya kepada BPJS. Bertanggung jawab berkewajiban menanggung, memikul, menanggung segala sesuatunya dan menanggung akibatnya. Tanggung jawab adalah kesadaran manusia akan tingkah laku atau perbuatannya yang disengaja maupun yang tidak disengaja. Tanggung jawab juga berarti berbuat sebagai perwujudan kesadaran atau kewajiban. Tanggung jawab itu bersifat kodrati dan hukum, artinya sudah menjadi bagian hidup manusia, bahwa setiap manusia dibebani dengan tanggung jawab, apabila dikaji tanggung jawab itu adalah kewajiban yang harus dipikul sebagai akibat dari perbuatan pihak yang berbuat. Tanggung jawab adalah ciri manusia yang beradab, manusia merasa bertanggung jawab karena ia menyadari akibat baik atau buruk perbuatannya itu, dan menyadari pula bahwa pihak lain memerlukan pengadilan atau pengorbanan. ${ }^{44}$

Pasal 55 menggunakan kata "atau" sehingga terpenuhinya unsur salah satu ayat dalam Pasal 19 ayat (1) atau ayat (2) telah dapat dikenakan sanksi pidana bagi perusahaan yang melanggarnya. Ketentuan pidana ini dibentuk agar kewajiban ini dapat dipaksakan sehingga hak-hak sosial dapat dijamin dengan terselenggaranya sistem jaminan sosial nasional.

Ilmu pengetahuan hukum pidana dikenal ada beberapa macam pembagian delik, menurut Satochid Kartanegara, dikenal dua jenis delik yaitu: formeel delict (delik formil) dan materieel delict (delik materiil). Yang dimaksud delik formil, yaitu delik yang dianggap telah "voltooid" (sepenuhnya terlaksana) dengan dilakukannya suatu perbuatan yang dilarang, contohnya Pasal 242 KUHP tentang sumpah palsu. Dalam ketentuan pidana UU BPJS yaitu Pasal 19 ayat (1) dan ayat (2) jo. Pasal 55 merupakan sebuah delik formil, karena tidak mengharuskan adanya akibat tertentu untuk dapat dipidana. Indah Sari yang mengutip Takdir Rahmadi menjelaskan, bahwadDelik Formil adalah delik atau perbuatan yang dilarang

${ }^{44}$ Julista Mustamu, 'Pertanggungjwbn Hukum Pemerintah' (2014) 20 Jurnal Sasi.[21]. 
oleh hukum yang sudah dianggap sempurna atau terpenuhi begitu perbuatan itu dilakukan tanpa mengharuskan adanya akibat dari perbuatan. ${ }^{45}$

Selain itu, delik dalam Pasal 19 ayat (1) dan ayat (2) jo. Pasal 55 tersebut merupakan delik aduan (klacht delicten). Delik aduan adalah salah satu jenis delik atau tindak pidana yang dalam rumusan delik dengan tegas dinyatakan, bahwa tindak pidana ini hanya dapat dituntut bila ada pengaduan dari yang berkepentingan. ${ }^{46}$ Misalnya delik yang diatur dalam Pasal 310 KUHP dan seterusnya tentang penghinaan, Pasal 284 tentang perzinahan, dan sebagainya. Delik aduan absolute misalnya delik yang diatur dalam Pasal 284, 310, 332 KUHP. Delik aduan relatif misalnya delik yang diatur dalam Pasal 367 KUHP tentang pencurian dalam keluarga. Delik biasa pelakunya dapat dituntut menurut hukum pidana tanpa perlu adanya pengaduan. ${ }^{47}$

Dalam delik Pasal 55 UU BPJS yang menjadi pengadu adalah BPJS sesuai dengan Pasal 11 huruf g UU BPJS, yang berbunyi:

“Dalam melaksanakan tugas sebagaimana dimaksud dalam Pasal 10, BPJS berwenang untuk:

g. melaporkan Pemberi Kerja kepada instansi yang berwenang mengenai ketidakpatuhannya dalam membayar iuran atau dalam memenuhi kewajibanlainsesuaidenganketentuanperaturanperundangundangan;"

Berdasarkan kewenangan BPJS, yang dapat mengadukan pelanggaran Pasal 19 ayat (1) dan ayat (2) jo. Pasal 55 UU BPJS ialah BPJS itu sendiri. Selain BPJS, pekerja di perusahaan yang bersangkutan dapat melaporkan kepada pihak yang berwenang karena terkait dengan hak-hak jaminan sosial yang ia miliki. Sebagai contoh dapat dilihat dalam Kasus pelanggaran 19 ayat (1) dan ayat (2) jo. Pasal 55 UU BPJS di Kota Surabaya dengan terdakwa SJH, yang dilaporkan oleh pekerjanya di Polda Jatim. ${ }^{48}$

\footnotetext{
${ }^{45}$ Indah Sari, ‘Unsur-Unsur Delik Materiel Dan Delik Formil Dalam Hukum Pidana Lingkungan' (2019) 10 Jurnal Ilmiah Hukum Dirgantara-Fakultas Hukum Universitas Dirgantara Marsekal Suryadarma.[64-80].

${ }^{46}$ Wempi Jh. Kumendong, 'Kemungkinan Penyidikan Delik Aduan Tanpa Pengaduan' (2017) 23 Jurnal Hukum Unsrat.[53-62].

${ }^{47}$ P.A.F. Lamintang, Op.Cit.[207].

${ }^{48}$ Radar Online, 'Pengusaha Asal Korea Enggan Bayar BPJS Akhirnya Diadili' <http:// radaronline.id/2018/07/11/ pengusaha-asal-korea-enggan-bayar-bpjs-akhirnya-diadili/>.
} 
Dalam Pasal 3 UU SJSN, disebutkan bahwa tujuan SJSN ialah untuk memberikan jaminan terpenuhinya kebutuhan dasar hidup yang layak bagi setiap peserta dan/atau anggota keluarganya. Penyelenggaraan SJSN dalam Pasal 4 UU SJSN berdasarkan prinsip kegotong-royongan, nirlaba, keterbukaan, kehati-hatian, akuntabilitas, portabilitas, kepesertaan bersifat wajib, dana amanat, dan hasil pengelolaan Dana Jaminan Sosial dipergunakan seluruhnya untuk pengembangan program dan untuk sebesar-besar kepentingan peserta.

Terdapat beberapa jenis jaminan sosial dalam UU SJSN, antara lain sebagai berikut:

a. Jaminan Kesehatan (Pasal 19 UU SJSN) Jaminan kesehatan diselenggarakan secara nasional berdasarkan prinsip asuransi sosial dan prinsip ekuitas. Jaminan kesehatan diselenggarakan dengan tujuan menjamin agar peserta memperoleh manfaat pemeliharaan kesehatan dan perlindungan dalam memenuhi kebutuhan dasar kesehatan. Peserta jaminan kesehatan adalah peserta jaminan kesehatan adalah setiap orang yang telah membayar iuran atau iurannya dibayar oleh Pemerintah, anggota keluarga peserta berhak menerima manfaat jaminan kesehatan, dan setiap peserta dapat mengikutsertakan anggota keluarga yang lain yang menjadi tanggungannya dengan penambahan iuran. ${ }^{49}$ Manfaat jaminan kesehatan bersifat pelayanan perseorangan berupa pelayanan kesehatan yang mencakup pelayanan promotif, preventif, kuratif dan rehabilitatif, termasuk obat dan bahan medis habis pakai yang diperlukan.

b. Jaminan Kecelakaan Kerja (Pasal 29 UU SJSN) Jaminan kecelakaan kerja diselenggarakan secara nasional berdasarkan prinsip asuransi sosial. Jaminan kecelakaan kerja diselenggarakan dengan tujuan menjamin agar peserta memperoleh manfaat pelayanan kesehatan dan santunan uang tunai apabila seorang pekerja mengalami kecelakaan kerja atau menderita penyakit akibat kerja. Peserta jaminan kecelakaan kerja adalah seseorang yang telah membayar

${ }^{49}$ Lihat dalam Pasal 20 Undang-Undang Nomor 40 Tahun 2004 tentang Sistem Jaminan Sosial 
iuran. ${ }^{50}$ Pasal 31 UU SJSN menyebutkan bahwa:

1) Peserta yang mengalami kecelakaan kerja berhak mendapatkan manfaat berupa pelayanan kesehatan sesuai dengan kebutuhan medisnya dan mendapatkan manfaat berupa uang tunai apabila terjadi cacat total tetap atau meninggal dunia;

2) Manfaat jaminan kecelakaan kerja yang berupa uang tunai diberikan sekaligus kepada ahli waris pekerja yang meninggal dunia atau pekerja yang cacat sesuai dengan tingkat kecacatan;

3) Untuk jenis-jenis pelayanan tertentu atau kecelakaan tertentu, pemberi kerja dikenakan urun biaya.

c. Jaminan Hari Tua (Pasal 35 UU SJSN) Jaminan hari tua diselenggarakan secara nasional berdasarkan prinsip asuransi sosial atau tabungan wajib. Jaminan hari tua diselenggarakan dengan tujuan untuk menjamin agar peserta menerima uang tunai apabila memasuki masa pensiun, mengalami cacat total tetap, atau meninggal dunia. Peserta jaminan hari tua adalah peserta yang telah membayar iuran. ${ }^{51}$ Pasal 37 UU SJSN menyebutkan bahwa:

1) Manfaat jaminan hari tua berupa uang tunai dibayarkan sekaligus pada saat peserta memasuki usia pensiun, meninggal dunia, atau mengalami cacat total tetap.

2) Besarnya manfaat jaminan hari tua ditentukan berdasarkan seluruh akumulasi iuran yang telah disetorkan ditambah hasil pengembangannya.

3) Pembayaran manfaat jaminan hari tua dapat diberikan sebagian sampai batas tertentu setelah kepesertaan mencapai minimal 10 (sepuluh) tahun.

4) Apabila peserta meninggal dunia, ahli warisnya yang sah berhak menerima manfaat jaminan hari tua.

5) Ketentuan sebagaimana dimaksud pada ayat (3) dan ayat (4) diatur lebih lanjut dalam Peraturan Pemerintah.

d. Jaminan Pensiun (Pasal 39 UU SJSN) Jaminan pensiun diselenggarakan secara nasional berdasarkan prinsip asuransi sosial atau tabungan wajib. Jaminan pensiun diselenggarakan untuk mempertahankan derajat kehidupan yang

\footnotetext{
Nasional.

${ }^{50}$ Lihat dalam Pasal 30 Undang-Undang Nomor 40 Tahun 2004 tentang Sistem Jaminan Sosial Nasional.

${ }^{51}$ Lihat dalam Pasal 36 Undang-Undang Nomor 40 Tahun 2004 tentang Sistem Jaminan Sosial
} 
layak pada saat peserta kehilangan atau berkurang penghasilannya karena memasuki usia pensiun atau mengalami cacat total tetap. Jaminan pensiun diselenggarakan berdasarkan manfaat pasti. Usia pensiun ditetapkan menurut ketentuan peraturan perundang-undangan. Peserta jaminan pensiun adalah pekerja yang telah membayar iuran..$^{52}$ Dalam Pasal 41 UU SJSN menyebutkan bahwa:

1) Manfaat jaminan pensiun berwujud uang tunai yang diterima setiap bulan sebagai:

a. Pensiun hari tua, diterima peserta setelah pensiun sampai meninggal dunia;

b. Pensiun cacat, diterima peserta yang cacat akibat kecelakaan atau akibat penyakit sampai meninggal dunia;

c. Pensiun janda/duda, diterima janda/duda ahli waris peserta sampai meninggal dunia atau menikah lagi;

d. Pensiun anak, diterima anak ahli waris peserta sampai mencapai usia 23 tahun, bekerja, atau menikah; atau

e. Pensiun orang tua, diterima orang tua ahli waris peserta lajang sampai batas waktu tertentu sesuai dengan peraturan perundang-undangan.

2) Setiap peserta atau ahli warisnya berhak mendapatkan pembayaran uang pensiun berkala setiap bulan setelah memenuhi masa iur minimal 15 (lima belas) tahun, kecuali ditetapkan lain oleh peraturan perundang-undangan.

3) Manfaat jaminan pensiun dibayarkan kepada peserta yang telah mencapai usia pensiun sesuai formula yang ditetapkan.

4) Apabila peserta meninggal dunia sebelum mencapai usia pensiun atau belum memenuhi masa iur 15 (lima belas) tahun, ahli warisnya tetap berhak mendapatkan manfaat jaminan pensiun.

5) Apabila peserta mencapai usia pensiun sebelum memenuhi masa iur 15 (lima belas) tahun, peserta tersebut berhak mendapatkan seluruh akumulasi iurannya ditambah hasil pengembangannya.

6) Hak ahli waris atas manfaat pensiun anak berakhir apabila anak tersebut menikah, bekerja tetap, atau mencapai usia 23 (dua puluh tiga) tahun.

7) Manfaat pensiun cacat dibayarkan kepada peserta yang mengalami cacat total tetap meskipun peserta tersebut belum memasuki usia pensiun.

8) Ketentuan mengenai manfaat pensiun sebagaimana dimaksud pada ayat (3), diatur lebih lanjut dalam Peraturan Presiden.

e. Jaminan Kematian (Pasal 43 UU SJSN) Jaminan kematian diselenggarakan secara nasional berdasarkan prinsip asuransi sosial. Jaminan kematian Nasional.

${ }^{52}$ Lihat dalam Pasal 40 Undang-Undang Nomor 40 Tahun 2004 tentang Sistem Jaminan Sosial 
diselenggarakan dengan tujuan untuk memberikan santunan kematian yang dibayarkan kepada ahli waris peserta yang meninggal dunia. Peserta jaminan kematian adalah setiap orang yang telah membayar iuran. Manfaat jaminan kematian berupa uang tunai dibayarkan paling lambat 3 (tiga) hari kerja setelah klaim diterima dan disetujui Badan Penyelenggara Jaminan Sosial. Besarnya manfaat jaminan kematian ditetapkan berdasarkan suatu jumlah nominal tertentu.

\section{Bentuk Pengaturan Klasifikasi Tindak Pidana Dalam Pasal 55 Undang-Undang No 24 Tahun 2011 tentang BPJS di Masa Mendatang}

Jika merujuk pada KUHP yang berlaku saat ini di Indonesia, maka tidak akan ditemukan pengertian dari korporasi. ${ }^{53}$ KUHP Indonesia hanya mengenal manusia (natuurlijk persoon) sebagai subjek hukum pidana. Guna menemukan definisi korporasi dalam hukum pidana, maka hal ini dapat berangkat dari Peraturan Mahkamah Agung dan beberapa pendapat para sarjana hukum. Dalam pasal 1 Peraturan Mahkamah Agung Nomor 13 Tahun 2016 tentang Tata Cara Penanganan Tindak Pidana Oleh Korporasi, Korporasi adalah kumpulan orang dan/atau kekayaan yang terorganisir, baik merupakan badan hukum maupun bukan badan hukum. Sesuai definisi tersebut, maka pemberi kerja masuk dalam kategori tersebut. Selanjutnya dari beberapa sarjana, menurut Rudi Prasetyo, kata korporasi merupakan sebutan yang lazim digunakan di kalangan pakar hukum pidana untuk menyebut apa yang biasa disebut sebagai badan hukum atau rechtspersoon dalam bahasa Belanda dan legal entities atau corporation dalam bahasa Inggris pada bidang hukum lain khususnya hukum perdata. ${ }^{54}$

Merujuk pada pengertian korporasi dalam hukum perdata, bahwa apa yang dimaksud korporasi itu adalah badan hukum, maka terhadap korporasi memiliki definisi tersendiri. R. Subekti mendefinisikan badan hukum pada pokoknya adalah

${ }^{53}$ Moeljanto, KUHP Kitab Undang-Undang Hukum Pidana, ed. Institute for Criminal Justice Reform (ICJR) (Institute for Criminal Justice Reform 2015).[3].

${ }_{54}$ Rudi Prasetya, 'Perkembangan Korporasi Dalam Proses Modernisasi Dan Penyimpangan-Penyimpangannya' (Universitas Diponegoro 1989).[2]. 
suatu badan atau perkumpulan yang dapat memiliki hak-hak dan melakukan perbuatan seperti manusia, serta memiliki kekayaan sendiri, dapat digugat atau menggugat di depan hakim.

Implementasi program-program jaminan sosial di BPJS Kesehatan dan BPJS Ketenagakerjaan mengalami dinamika yang beragam. Seperti halnya dalam BPJS Kesehatan antusias masyarakat meningkat dalam mengakses layanan kesehatan. Sebagai contoh total dana yang dikeluarkan BPJS Kesehatan untuk pelayanan di Fasilitas Kesehatan Tingkat Pertama dan Fasilitas Kesehatan Tingkat Lanjutan pada tahun 2016 mencapai Rp. 79 Triliun, pada tahun 2017 meningkat menjadi Rp. 96,7 triliun. $^{55}$

Implementasi Jaminan Sosial Ketenagakerjaan menyisakan sejumlah permasalahan, antara lain target kepesertaan Jaminan Sosial Ketenagakerjaan yang ditetapkan dalam Peta Jalan pada Tahun 2017 adalah sebanyak 53.325.698 jiwa, namun dalam realisasinya sampai dengan bulan Juni 2018 baru mencapai 27.999.455 jiwa. Angka ini baru mencapai 47,5 \% dari target yang ditetapkan dalam Peta Jalan.

Program Jaminan Hari Tua dalam implementasinya belum sesuai dengan filosofi awal yang diamanatkan dalam UU Sistem Jaminan Sosial Nasional, karena masih terdapat segmentasi kepesertaan khususnya bagi ASN dan TNI/POLRI serta nelayan.

Menurut Molengraff, pengertian perusahaan dari sudut ekonomi adalah keseluruhan perbuatan yang dilakukan secara terus menerus, bertindak keluar, untuk memperoleh penghasilan, dengan cara memperdagangkan atau menyerahkan barang atau mengadakan perjanjian perdagangan. Perusahaan dalam UU BPJS termasuk dalam pengertian Pemberi Kerja, adapun Pemberi Kerja ialah orang perseorangan, pengusaha, badan hukum, atau badan lainnya yang memperkerjakan tenaga kerja atau penyelenggara negara yang mempekerjakan pegawai negeri dengan membayar gaji, upah, atau imbalan dalam bentuk lainnya..$^{56}$

\footnotetext{
${ }^{55}$ Sigit Priohutomo, Op.Cit.

56 ibid.
} 
Perusahaan sebagai pemberi kerja secara bertahap wajib mendaftarkan dirinya dan pekerjanya sebagai peserta kepada BPJS sesuai dengan Program Jaminan Sosial yang diikuti. Berdasarkan Pasal 17 UU BPJS, perusahaan yang tidak mendaftarkan dirinya dan pekerjanya akan dikenakan sanksi administratif antara lain teguran tertulis, denda dan/atau tidak mendapat pelayanan tertentu.

Tanpa memperhatikan kearifan lokal, berbagai kebijakan akan menjadi timpang, dan kurang akomodatif. Diterapkannya sanksi administratif kepada perusahaan yang tidak mendaftarkan dalam BPJS dikarenakan tidak efektifnya pencantuman sanksi pidana pada peraturan sebelumnya, tujuan pencantuman yang harapannya untuk memberikan perlindungan hukum kepada pekerja, justru mengancam keberlangsungan hubungan kerja antara pekerja dengan perusahaan. ${ }^{57}$ Penghapusan sanksi pidana sesuai dengan tujuan penyelenggaraan jaminan sosial, yaitu untuk mendapatkan kepesertaan yang sebanyak-banyaknya sebagai wujud dari hak konstitusional warga Negara..$^{58}$

Perusahaan yang telah menjadi peserta BPJS, berdasarkan Pasal 19 ayat (1) dan ayat (2) UU BPJS, perusahaan berkewajiban untuk:

Pasal 19 ayat (1)

“Pemberi Kerja wajib memungut iuran yang menjadi beban Peserta dari Pekerjanya dan menyetorkannya kepada BPJS".

Pasal 19 ayat (2)

“Pemberi Kerja wajib membayar dan menyetor Iuran yang menjadi tanggung jawabnya kepada BPJS".

Dari kedua pasal tersebut perusahaan yang sudah menjadi peserta BPJS wajib untuk memungut iuran, membayar dan menyetor iuran yang menjadi beban peserta dari pekerjanya kepada BPJS. Dalam UU BPJS memberikan sanksi pidana bagi perusahaan yang melanggar Pasal 19 ayat (1) dan ayat (2) yang diatur dalam Pasal 55 UU BPJS. Adapun bunyi pasal 55 UU BPJS antara lain:

“Pemberi Kerja yang melanggar ketentuan sebagaimana dimaksud dalam Pasal 19 ayat (1) atau ayat (2) dipidana dengan pidana penjara paling lama 8

${ }^{57}$ Ratih Dheviana Puru Hitaningtyas, Op.Cit.[31].

${ }^{58}$ ibid. 
(delapan) tahun atau pidana denda paling banyak Rp. 1.000.000.000,00 (satu miliar rupiah)".

Terlihat bahwa UU BPJS sangat ketat dalam menertibkan perusahaan untuk melaksanakan Pasal 19 ayat (1) dan ayat (2) yang menjadi kewajibannya setelah menjadi peserta BPJS. Namun, dari konstruksi dalam Pasal 19 ayat (1) dan ayat (2) jo. Pasal 55 UU BPJS terdapat kekaburan norma (vague norm).

Perbaikan atau penyempurnaan terhadap permasalahan dalam ketentuan pidana bagi perusahaan yang tidak membayarkan iuran BPJS bisa dilakukan dengan membuat skema keterlambatan yang menjunjung kepastian hukum. Kepastian hukum disini berarti ada indikator yang pasti dalam menentukan perusahaan tersebut terlambat atau tidak memenuhi kewajiban untuk membayar iuran BPJS. Rumusan di masa yang akan datang bisa memberikan indikator dari waktu keterlambatan. Misalkan saja:

a. Lancar, perusahaan melakukan keterlambatan dalam 1-3 bulan;

b. Kurang lancar, perusahaan melakukan keterlambatan dalam 4-6 bulan;

c. Diragukan, perusahaan melakukan keterlambatan 7-12 bulan; dan

d. Macet, perusahaan melakukan keterlambatan $>12$ bulan.

Dengan memberikan indikator tersebut, tentu perusahaan tidak akan ada alasan untuk mengelak terlambat atau telah memenuhi ketentuan pidana dalam UU BPJS. Begitu pula terhadap aparat penegak hukum yang tentu akan menindak perusahaan yang telah memenuhi unsur ketentuan pidana dalam UU BPJS di masa yang akan datang. Sehingga jaminan sosial dan kesehatan yang menjadi kewajiban neagara dapat terpenuhi.

\section{Kesimpulan}

Kesimpulan dari pembahasan di atas ialah urgensi Pengaturan Klasifikasi Tindak Pidana Dalam Pasal 55 Undang-Undang Nomor 24 Tahun 2011 tentang BPJS ialah bahwa suatu peraturan perundang - undangan yang berlaku harus mempunyai kepastian hukum, efektivitas norma dan kemanfaatan hukum. Kepastian hukum ialah merupakan pelaksanaan hukum sesuai dengan bunyinya sehingga masyarakat dapat memastikan bahwa hukum dilaksanakan dapat 
memberikan informasi yang jelas kepada pemberi kerja apa yang menjadi hak dan kewajibannya dan akan sanksi yang diberlakukan atas pelanggaran terhadap pelaksanaan yang ada dan bagi para pekerja untuk mendapatkan kepastian dalam pelayanan kesehatan dan jaminan sosial. Efektivitas norma agar ketentuan pidana dalam UU BPJS dapat dilaksanakan dan diterapkan kepada perusahaan yang sengaja/melawan hukum tidak memenuhi kewajibannya sebagai anggota BPJS. Dan kemanfaatan hukum secara umum akan didapatkan ketika norma dan kepastian hukum dalam UU BPJS terlaksana.

Bentuk pengaturan klasifikasi tindak pidana dalam Pasal 55 UndangUndang No 24 Tahun 2011 tentang BPJS di masa yang akan datang dilakukan dengan membuat skema keterlambatan yang menjunjung kepastian hukum. Indikator yang pasti dalam menentukan perusahaan tersebut terlambat atau tidak memenuhi kewajiban untuk membayar iuran BPJS. Rumusan di masa yang akan datang bisa memberikan indikator dari waktu keterlambatan. Dan saran untuk pembuat kebijakan, diharapkan dengan adanya kepastian hukum dalam UU No. 24 tahun 2011 tentang BPJS pencapaian target kepesertaan dan iuran BPJS dapat terpenuhi sesuai dengan target yang sudah diharapkan dan bagi akademisi dapat menambah wawasan dan pemahaman tentang pentingnya klasifikasi tindak pidana dalam UU Nomor 24 tahun 2011 tentang BPJS sebagai kajian atau Analisa untuk menemukan dan membuat klasifikasi baru tentang tindak pidana dalam UU BPJS yang akan datang dengan mengacu pada perubahan sosial dalam masyarakat.

\section{Daftar Bacaan}

\section{Buku}

Andi Hamzah, Asas-Asas Hukum Pidana (Rineka Cipta 2010).

Andrisman T, Hukum Pidana (Asas-Asas Dan Dasar Aturan Umum Hukum Pidana Indonesia) (Universitas Lampung Press 2009).

Barda Nawawi Arif, Bunga Rampai Hukum Pidana (Citra Aditya Bhakti 1996). 
Deliarnov, Ekonomi Politik (Erlangga 2006).

Kaelan, Pendidikan Pancasila Edisi Reformasi (Paradigma 2010).

Leden Marpaung, Asas - Teori - Praktik Hukum Pidana (Cetakan Ke, Sinar Grafika 2008).

Marzuki PM, Pengantar Ilmu Hukum (Kencana Press 2008).

Justice Reform (ICJR) ed, Institute for Criminal Justice Reform 2015).

Muhammad A, Hukum Perusahaan Indonesia (Citra Aditya Bhakti 2006).

P.A.F. Lamintang, Dasar-Dasar Hukum Pidana Indonesia (2nd edn, Sinar Baru 1990).

Rahardjo S, Hukum Dalam Jagat Ketertiban (UKI Press 2006).

Sanica IG, Paradigma Baru Akuntabilitas Keuangan: Sebuah Tinjauan Kelembagaan Organisasi Subak Jatiluwih Tabanan Bali (Pusaka Abadi 2019).

Tirtaamidjaja, Pokok-Pokok Hukum Pidana (Fasco 1955).

Jurnal

Alfitri A, ‘Ideologi Welfare State Dalam Dasar Negara Indonesia: Analisis Putusan Mahkamah Konstitusi Terkait Sistem Jaminan Sosial Nasional' (2012) 9 Jurnal Konstitusi.

Candra S, ‘Perumusan Ketentuan Pidana Dalam Peraturan Perundang-Undangan Di Indonesia' (2013) 3 Jurnal Hukum Prioris.

- - , 'Perumusan Ketentuan Pidana Dalam Peraturan Perundang-Undangan Di Indonesia' (2013) 3 Jurnal Hukum Prioris.

ELVIANDRI E, ‘Quo Vadis Negara Kesejahteraan: Meneguhkan Ideologi Welfare State Negara Hukum Kesejahteraan Indonesia' (2019) 31 Mimbar Hukum Fakultas Hukum Universitas Gadjah Mada.

Hardinanto A, 'Manfaat Analogi Dalam Hukum Pidana Untuk Mengatasi Kejahatan Yang Mengalami Modernisasi' (2016) 31 Jurnal Yuridika.

Hitaningtyas RDPHDP, ‘Penghapusan Sanksi Pidana Terkait Kewajiban Pemberi Kerja Untuk Mengikutsertakan Pekerjanya Dalam Program Jaminan Sosial’ (2017) 2 Jurnal Panorama Hukum. 
Kadarisman M, 'Analisis Tentang Pelaksanaan Sistem Jaminan Sosial Kesehatan Pasca Putusan Mahkamah Konstitusi No. 07/Puu-Iii/2005’ (2015) 22 Jurnal Hukum Ius Quia Iustum.

Kumendong WJ, 'Kemungkinan Penyidikan Delik Aduan Tanpa Pengaduan' (2017) 23 Jurnal Hukum Unsrat.

Luh N and others, 'Logika Hukum Dan Terobosan Hukum Melalui Legal Reasoning' (2016) 31 Jurnal Hukum Jatiswara.

Manullang EFM, 'Sesat Pikir Aplikasi Hermeneutika Hukum Menurut HansGeorg Gadamer' (2018) 48 Jurnal Hukum \& Pembangunan.

Mashendra, 'Perampasan Aset Korupsi Dalam Upaya Pemberantasan Tindak Pidana Korupsi Menurut Hukum Pidana Indonesia' (2020) 8 Jurnal Petitum.

Sari I, 'Unsur-Unsur Delik Materiel Dan Delik Formil Dalam Hukum Pidana Lingkungan' (2019) 10.

Sitompul E, Anzward B and Praharafi G, 'KEKERASAN LEGAL LIABILITY AGAINST VICTIMS OF SELF-DEFENSE RESULTING IN DEATH OF CRIMINAL THEFT WITH VIOLENCE Artikel' (2020) 2 Jurnal Lex Suprema.

Supriyadi S, 'Penetapan Tindak Pidana Sebagai Kejahatan Dan Pelanggaran Dalam Undang-Undang Pidana Khusus' (2016) 27 Mimbar Hukum.

Zaelani, 'Komitmen Pemeritah Dalam Penyelenggara Dalam Jaminan Sosial Nasional' (2012) 9 Jurnal Legislasi Indonesia.

\section{Laman}

I Gusti Ngurah Parwata, 'Mata Kuliah Tindak Pidana Khusus' https://simdos.unud. ac.id/.

Industrycoid, 'Ketua DJSN: Hingga Tahun Ke-5, Implementasi UU SJSN Diwarnai Berbagai Dinamika Yang Berkembang, (Online)' (2020) http://www. industry.co.id/read/39258/ketua-djsn-hingga-tahun-ke-5-implementasiuu-sjsn-diwarnai -berbagai-dinamika-yang-berkembang.html.

Julyano M and Sulistyawan AY, 'Nomor 01' (2019) 01 Jurnal Crepido 13 https:/ / ejournal2.undip.ac.id/index.php/crepido/.

Kementerian Kesehatan Republik Indonesia, 'Data Dan Informasi Profil Kesehatan Indonesia 2017' http://www.depkes.go.id/article/view/18042300004/ lampiran-data-profil-kesehatan-indonesia2017. 
Moeljanto, KUHP Kitab Undang-Undang Hukum Pidana (Institute for Criminal).

Mujibussalim, Sanusi and Fikri, 'Jaminan Sosial Kesehatan: Integrasi Program Jaminan Kesehatan Aceh Dalam Sistem Jaminan Sosial Nasional' (2013) 13 Jurnal Dinamika Hukum 229 http://dinamikahukum.fh.unsoed.ac.id/ index.php/JDH/article/viewFile/206/154.

Mustamu J, 'Pertanggungjwbn Hk Pemerintah' (2014) 20 Jurnal Sasi 21 file:/ / C:/ Users/Indah Cahyani/Downloads/jsasi_2014_20_2_mustamu_21-27.pdf.

Radar Online, 'Pengusaha Asal Korea Enggan Bayar BPJS Akhirnya Diadili' http:/ / radaronline.id/2018/07/11/pengusaha-asal-korea-enggan-bayarbpjs-akhirnya-diadili/.

Shidarta, 'Asas Legalitas' https://business-law.binus.ac.id/2016/02/02/asas-legalitas/

\section{Karya Ilmiah}

Rudi Prasetya, 'Perkembangan Korporasi Dalam Proses Modernisasi Dan Penyimpangan-Penyimpangannya', Makalah disampaikan pada Seminar Nasional Kejahatan Korporasi di FH UNDIP (1989). 
--Halaman ini sengaja dibiarkan kosong-- 